\title{
Adsorption of Sulfur Dioxide in Gaseous Phase on the Porous $\boldsymbol{m}$-Aminophenol Condensation Resins ${ }^{\dagger}$
}

Isao Hashida and Masato Nishimura

Osaka Municipal Technical Research Institute; Kitaogi-machi, Kita-ku, Osaka-shi, Japan

Adsorption equilibrium of sulfur dioxide on the $m$-aminophenol resins with various pore structures was measured gravimetrically at the temperature range of $20 \sim 60^{\circ} \mathrm{C}$ and equilibrium pressure up to $760 \mathrm{mmHg}$. Heats of adsorption were estimated as 14 to $15 \mathrm{kcal} / \mathrm{mol}$ using Clausius-Clapeyron equation. Apparent activation energy of adsorption of sulfur dioxide was calculated as $-1 \mathrm{kcal} / \mathrm{mol}$ from Arrhenius plot. Adsorption capacity of the resins for sulfur dioxide was measured dynamically, by circulating sulfur dioxide $\left(1.77 \%\right.$ in $\left.\mathrm{N}_{2}\right)$ over the resins at the flow velocity of $76 \mathrm{~cm} / \mathrm{min}$ at ambient temperature and pressure, and was compared with that of macroreticular and gel type quaternary ammonium anion-exchange resins in the $\mathrm{R}-\mathrm{OH}$ form. The adsorption capacity of highly porous resins for sulfur dioxide was 29 to $30 \mathrm{~m} l$-STP/g-dry resin. Adsorption reached nearly equilibrium over the porous resin with ten minutes.

$\dagger$ Adsorption of Gas on Ion Exchangers. V.

（日本化学会誌, 1972, p. 184 188)

\section{ポリメタクリル酸メチルを基体とするカチオン性 高分子の合成とその凝集効果"}

（1971 年 8 月 14 日受理）

江川博明・野中敬正・池口信之*

ポリメタクリル酸メチル (PMMA) をボทエチレンポリフミンと反态させて氷溶性高分子を合成し，カチオン性凝

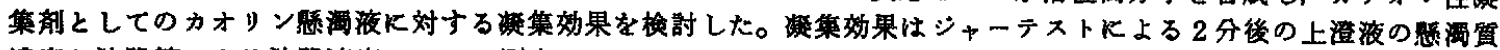
渡度と沈降管による讨降速度について濉定した。

PMMA に対してジチルホルムフミドを溶媒としてポリェチレンポリフミンを 5〜7倍モル使用し，170〜180C,

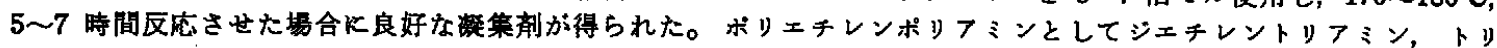
エチレンテトラミン,テトラエチレンペンタミンと反応させて得られたるのはその清澄効果にほとんど差は認められ

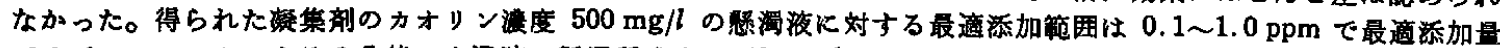
でのジャーテストKよる 2 分後の上澄液の笔摆質篧度は $40 \mathrm{mg} / \mathrm{l}$ 以下であった。最適使用 $\mathrm{pH}$ 範囲は $\mathrm{pH} 2.5 \sim 8.5$ であった。沈降速度はカオリンに対する使用量が $0.004 \%$ で最高速度 $5.25 \mathrm{~cm} / \mathrm{min}$ を示した。

\section{1 楮骨}

現在，用水の確保のためまた産業排水の清澄化のために高分子 凝集珴が大きく注目されている。従来江硫酸アルミニウムなとの 無機凝集剤が多々使用されていたが近年種々の高分子凝集剤が開 発され，少量の添加量で良好な凝集効果を示すことが認められ， その使用量も年々増加している。天然拈よび多くの㦟濁質は水中 では負の荷電を有しておりそれらを含む廃水の処理机カチオン 性高分子凝集剂がとくに有効である。現在玉で㐸多くのカチオン 性高分子凝集削が研究されている。その中でポリアミン采凝集郕

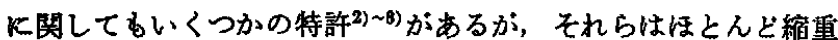

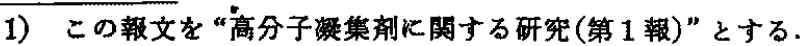

* 熊本大学工学部, 熊本市黒鲛町
合物であり，そのため分子量を十分大きくすることができずまた 均筫なるのをつくるのが困難である。ポリマーにポリ、ミンを反 応させたすのとしてはポリアクリル酸メチルにジアミン,トリア ミンタを蛙よびポリアクリロニトリルにポリアルキレンジアミン を反忘させたすの ${ }^{10)}$ がある。著者らは良好な凝集効果をすつ新し

2) D.C. Garms, U.S.P., 3, 275, 588(1966).

3）三木正之，伊藤煇彦，三井 中，前田晴一郎，三谷孝夫， 日特公, 昭和 41-17452.

4）桑原富士雄，久保堅，椇達男，日特公，昭和 41-20929.

5) W.D. Emmons, U.S.P., 3, 305, 493(1967)

6) J. Fertig, H. H. Stockmann, Fr.P., 1, 534, 146(1968)

7) B. M. Rushton, U.S.P., 3, 445, 441(1969).

8) R.J. Pratt, R.K. Diefenbach, U.S.P., 3, 507, 787 (1970).

9) S. Melamed, U.S.P., 2, 845, 408(1958).

10) J. H. Marvin，A. Harvart，日特公，昭和 42-9653. 
い高分子凝集郕の製造を目的として基礎研究を行なってきた。本 報ではポリメタクリル酸メチルをポリエチレンポリアミンと反応 させて水溶性高分子を合成し，カチオン性凝集剂としての性質を カオリン愁濁液に対する凝集好果について検討した。

\section{2 实倹}

\section{1 高分子疑集剂の合成}

2.1.1 ボリメタクリル酸メチル (PMMA) の合成：メタクリ ル酸メチルモノマー（三菱レイヨン株式会社製品）は，1 N 水酸 化ナトリウム溶液で数回洗浄し，つぎ純水でアルカリ性を示さ なくなるまで洗浄して禁止剤を除いたものを使用した。重合は封 管中で過酸化ベンゾイル（BPO）を開始唷として所定の温度 (30 $\sim 100^{\circ} \mathrm{C}$ ) で重合し，重合物を大量のメタノールK投入して沈 殿 させてその沈段物をアセトンに溶解し再度メタノシルに沈股させ た。この操作により未反応のモノマーおよび開始珴を除去した。 その後風乾してさらに $50 \sim 60^{\circ} \mathrm{C}$ で真空乾燥を $2 \sim 3$ 時間行なっ たものをアミノ基導入の陚料とした。

2.1.2・PMMA ヘのアミノ基の荋入 : PMMA $1 \mathrm{~g}$ をポりエチ レンポリアミンの所定量（PMMA のエステル基に対し 3〜10 倍 モル）と耐王試験管中で直接反応させる方法，またはPMMA $1 \mathrm{~g}$ をジメチルホルムアミド (DMF) の所定量 $(40 \sim 80 \mathrm{ml})$ に溶解 したのち，ポリェチレンポリアミンと所定温度 $\left(130 \sim 200^{\circ} \mathrm{C}\right)$ で 所定時間（3〜10 時間）反応させる方法を用いた。ポりエチレン ポリアミンとしてはシェル石油株式会社製のジェチレントリアミ ン (DTA), トリエチレンテトラミン (TTA), テトラエチレン ペンタミン (TPA) を減圧蒸留して精製したるのを使用した。反 応生成物を水に溶解し，セロファンチューブを使って水による透 析を 72 時間行ない未反応のポリエチレンポリアミンおよび溶媒 を除去した。透析後，濃度を蒸発乾固法により求めて使用時の溶
液の濃度の調雙を行なった。

\section{1 .3 蒠入アミ/基の定量：アミノ基尊入後の反応物をテト} ラヒドロフラン (THF) 中に投入してポyマーを沈殿させ,一度 風鞋させたのち，THFで 30 時間ソックスレ一抽出を行なって

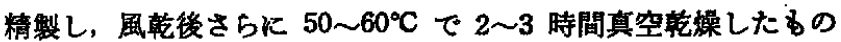
を試料として元素分析により窒素の定量を行なった。空菜の含有 量からポリマー中のエステル基が何\%反応したかを求めた。

\section{2 㕠集試唯}

実験はすべて 22〜26 C 室温中で行なった。

2.2.1 カオリン酳濁洨 : 和光純薬の局方カオリンを 105〜110

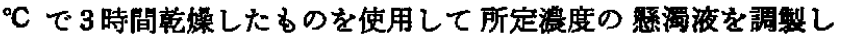
た。 $500 \mathrm{mg} / l$ 拈よび $5 \%$ のカオリン悬濁液の $\mathrm{pH}$ は 7.55 およ び 7.70 であった。

2.2.2 清登度貺定：ジャーテスダーを使用し, $500 \mathrm{mg} / \mathrm{l}$ のカ

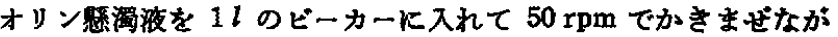
ら 100 または $1000 \mathrm{mg} / \mathrm{l}$ の濃度に調製した凝集剂溶液を所定母 添加し， 2 分間急速かきまぜを行ない，つづいて 15 分間緩速かき まぜを行なったのち 2 分間静置してその上澄液を約 $20 \mathrm{ml}$ とり， 濁度を测定し，あらかじめ作制して括いた標準濁度険量線から上 澄液の㲘溜質漊度 $(\mathrm{mg} / \mathrm{l})$ を求めた。

2.2.3 沈降速度測定：5\%のカオリン眯濁液を目盛付試 験管 $(18 \times 180 \mathrm{~mm})$ 飞 $25 \mathrm{ml}$ 入れ，漊度 $100 \mathrm{mg} / l$ または $1000 \mathrm{mg} / \mathrm{l}$ の凝集用溶液を所定墨添加し 4 秒間に 1 回の速度で 25 回転倒し

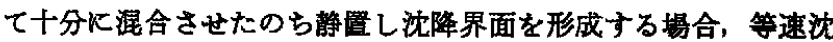
降城での沈降界面の沈降速度を測定した。

\section{3 結果むよひ考晜}

\section{1 反応条件と凝基効果}

3.1.1 アミノ基算入法の検封 : PMMA とポりェチレンポリア

Table 1 Aminolysis of polymethylmethacrylate by different amine

\begin{tabular}{|c|c|c|c|c|c|c|c|c|c|c|c|}
\hline \multirow[b]{2}{*}{$\begin{array}{l}\text { Expt. } \\
\text { No. }\end{array}$} & \multirow[b]{2}{*}{$\begin{array}{c}\left.\mathrm{PMMA}^{a}\right) \\
(\mathrm{g})\end{array}$} & \multirow[b]{2}{*}{$\begin{array}{l}\mathrm{DMF} \\
(\mathrm{m} l)\end{array}$} & \multicolumn{3}{|c|}{ Amine } & \multirow{2}{*}{$\begin{array}{c}\text { Tempe- } \\
\text { rature } \\
\left({ }^{\circ} \mathrm{C}\right)\end{array}$} & \multirow[b]{2}{*}{$\begin{array}{l}\text { Time } \\
\text { (hr) }\end{array}$} & \multirow[b]{2}{*}{$\begin{array}{l}\text { Yield }^{(b)} \\
(g)\end{array}$} & \multirow[b]{2}{*}{$\begin{array}{c}N \\
(\%)\end{array}$} & \multirow{2}{*}{$\begin{array}{c}\text { Conver- } \\
\text { sion } \\
(\%)\end{array}$} & \multirow{2}{*}{$\begin{array}{l}\text { Symbol of } \\
\text { products }\end{array}$} \\
\hline & & & kinds & $\begin{array}{l}\text { amount } \\
(\mathrm{m} l)\end{array}$ & $\underset{(\mathrm{mol} / \mathrm{mol})}{\operatorname{amine} / \mathrm{PMMA}}$ & & & & & & \\
\hline 1 & 1 & 40 & TTA & 10.6 & 7 & 130 & 7 & 0.79 & 5.9 & 12.0 . & PMT-1a \\
\hline 2 & 1 & 40 & TTA & 10.6 & 7 & 150 & 7 & 1.07 & 12.3 & 29.3 & $-1 \mathbf{b}$ \\
\hline 3 & 1 & 40 & TTA & 10.6 & 7 & 175 & 7 & 1.17 & 15.2 & 39.3 & $-1 c$ \\
\hline 4 & 1 & 40 & TTA & 10.6 & 7 & 200 & 7 & - & - & - & $-1 d$ \\
\hline 5 & 1 & 40 & TTA & 10.6 & 7 & 175 & 3 & 0.74 & 14.5 & 36.7 & PMT-2a \\
\hline 6 & 1 & 40 & TTA & 10.6 & 7 & 175 & 5 & 0.85 & 15.3 & 39.7 & $-2 b$ \\
\hline 7 & 1 & 40 & TTA & 10.6 & 7 & 175 & 7 & 1.17 & 15.2 & 39.3 & $-2 c$ \\
\hline 8 & 1 & 40 & TTA & 10.6 & 7 & 175 & 10 & 1. 46 & 15.3 & 39.7 & $-2 d$ \\
\hline 9 & 1 & 50.7 & TTA & 4.4 & 3 & 175 & 7 & 1.02 & 14.2 & 35.7 & PMT-3a \\
\hline 10 & 1 & 47.5 & TTA & 7.6 & 5 & 175 & 7 & 1.18 & 15.0 & 38.6 & $-3 b$ \\
\hline 11 & 1 & 44.5 & TTA & 10.6 & 7 & 175 & 7 & 1.17 & 15.6 & 40.8 & $-3 c$ \\
\hline 12 & 1 & 40 & TTA & 15.1 & 10 & 175 & 7 & 1.36 & 16.0 & 42.4 & $-3 d$ \\
\hline 13 & 1 & 40 & $\mathrm{DTA}^{(d)}$ & 7.6 & 7 & 175 & 7 & 1. 38 & 13.3 & 40.8 & PMD \\
\hline 14 & 1 & 40 & TTA $\left.^{e}\right)$ & 10.6 & 7 & 175 & 7 & 1.57 & 15.2 & 39.3 & PMT \\
\hline 15 & 1 & 40 & TPA $^{\prime \prime}$ & 13.6 & 7 & 175 & 7 & 1.55 & 15.5 & 34.0 & PMP \\
\hline
\end{tabular}

a) PMMA was prepared by the polymerization for 1.5 hours at $60^{\circ} \mathrm{C}$ using $0.5 \% \mathrm{BPO}$ as initiator and had molecular weight of 289 thousands.

b) This is yield of water-soluble polymer.

c) Conversion was represented the proportion of ester groups reacted with amines.

d) Diethylenetriamine.

e) Triethylenetetramine.

f) Tetraethylenepentamine. 
ミンとの反応において水溶性高分子を得るための反応方法を検討 した。PMMA とポりエチレンポリアミンを直接反応させた場合 飞性反応生成物中水に可溶な部分が少なく，本溶性高分子を得る ためには適当な方法ではない。PMMAをDMFに溶解したのち ポリエチレンポリアミンと反応させると適当な条件下では $100 \%$ 水に可溶な反応生成物が得られた。これは溶媒の使用に上り反応 が均一炕行なわれたためと反応マミンによる高分子間の橋かけ反 応が起こりにくくなったためと考えられる。同じ分子量をるっ PMMA の場合，いずれの方法によっても得られた水溶性高分子 によるカオリン䜿濁液に対する清澄効果にはほとんど差が認めら れなかった。以上の結果から本研究の目的である高分子凝集郕と しての水溶性高分子の取率をあげるためには溶媒を使用する方法 が適当と思われる。以下に DMF を溶媒として使用し良好な凝集 効果をるつ水溶性高分子を得るための最適反応条件を検討した。

3.1 .2 反応温度市よひ時間の影策 : BPO $0.5 \mathrm{wt} \%$ を開始剂 として $60^{\circ} \mathrm{C}$ で重合して得られた分子量 289000 の PMMA を DMF を溶媒として使用し，種々の条件で反応を行ない，得られ た凝集剤の清澄効果をジャーテストにより検討し，また生成物の 性状（表 1）加考察して最良の反応条件を求めた。まず TTA を 7 倍モル使用し $130 ， 150 ， 175$ および $200^{\circ} \mathrm{C}$ で 7 時間反応を 行ない，得られた水溶性高分子中の窒素の含有量を求めてポリマ 一のエステル基とボリエチレンポリアミンとの反応率を求めた。 結果は表 1 の No. 1 4 4゙ある。130 $\mathrm{C}$ で反応させたりのは反応

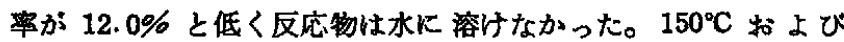
$175^{\circ} \mathrm{C}$ で反応させたるの恃 $29.3 \%$ および $39.3 \%$ の反度率を示

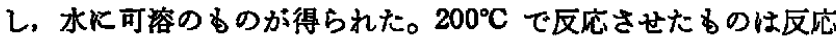
途中ゼリー状になり水に溶けなかった。これは高温のためア゙ミン に上る高分子間の橋かけ反応が起こったためと考える。

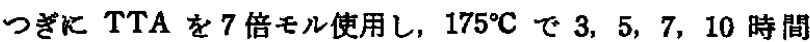
反応させて得られた频集剤の清澄効果を図 1 亿示す。

1 時間反応生成物は浪とんと清澄効果を示さなかった。反応時

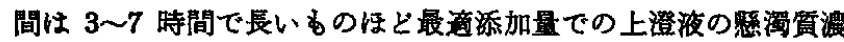
度はわずかではあるが低くなり，10 時間のるのは 7 時間の場合

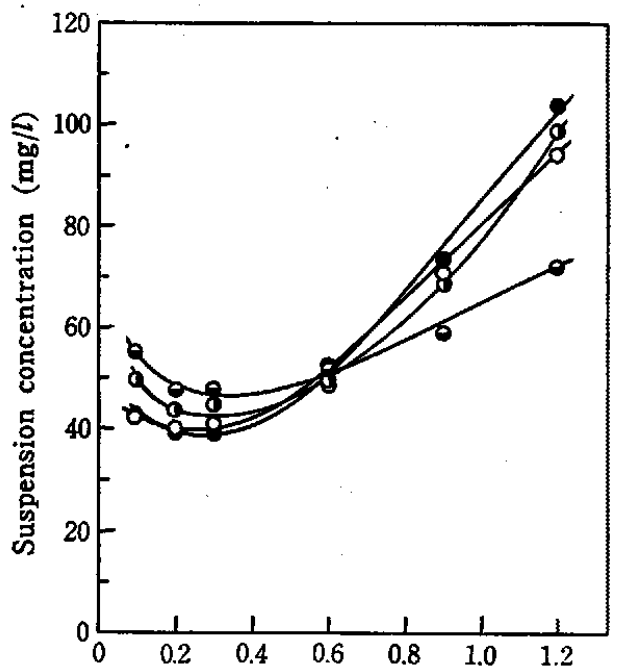

Amount of flocculants added (ppm)

Fig. 1 Effect of reaction time with amine $\Theta:$ PMT $-2 a, 0:$ PMT $-2 b, O: P M T-2 c$, : PMT-2 d (See Table 1)
とほとんど変わらなかった。得られた水溶性高分子（夆1.の No. 5〜8 参照) は穻素の含有量にほとんど差が認められないので反 応条件は $175^{\circ} \mathrm{C} ， 5 \sim 7$ 時間が適当である。またこ的の高分子 凝集剤の最適添加範囲は 0.1〜 $1.0 \mathrm{ppm}$ であっだ。そか山トの添 加量になると上澄液の憼濁質濃度はふたたび高くなった。このこ

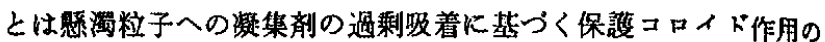
ためであると解积されている

3.1 .3 反応韋此の影㗽 : PMMA のエステル基に対し何倍モル のポリエチレンポリアミンを使用したときに氷溶性高分子が取率 よく得られ，しかも清澄効果の良效なるのが得られるかを検討し た。PMMA $1 \mathrm{~g}$ をDMF $40 \mathrm{ml}$ に溶解したのち、ポりェキレン ポリアミンを 3〜10 倍モル加え， $175^{\circ} \mathrm{C}, 7$ 時間反応させたとこ ろ，3，5 倍モルの場合は一部水に不溶のものが得られた。つき に反応系の全量がアミン10 倍モル量添加の場合と同一 $(55.1 \mathrm{ml})$

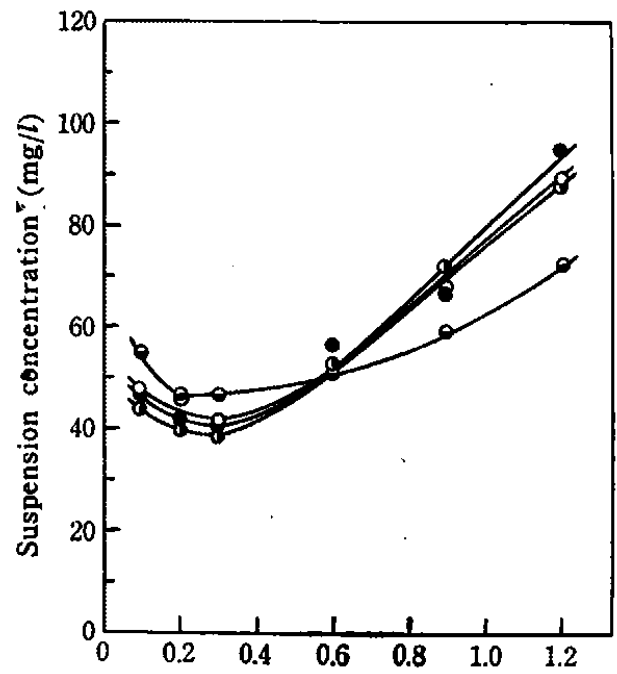

Amount of flocculants added (ppm)

Fig. 2 Effect of the amine concentration 0 : PMT-3 a, O : PMT-3 b, : PMT-3c, O : PMT-3 d (See Table 1)

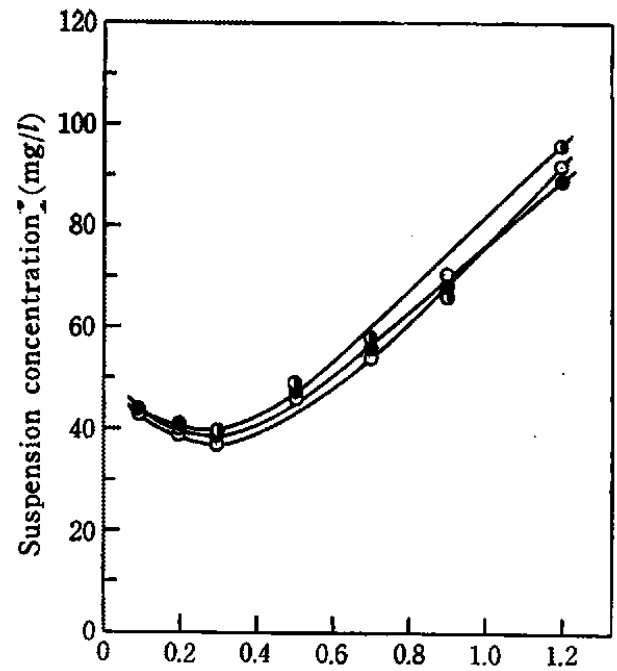

Amount of flocculants added (ppm)

Fig. 3 Effect of the various amino groups introduced to the flocculants

O : PMD, : PMT, O : PMP (See Table 1)

11）野田道宏，日化，82，1161(1961)。 
Table 2 Aminolysis of PMMA having different molecular weights

Aminolysis

\begin{tabular}{|c|c|c|c|c|c|c|c|c|c|c|}
\hline \multirow{2}{*}{$\begin{array}{l}\text { Expt. } \\
\text { No. }\end{array}$} & \multicolumn{6}{|c|}{ Conditions } & \multirow[b]{2}{*}{$\begin{array}{l}\text { Yield }^{b)} \\
(g)\end{array}$} & \multicolumn{3}{|c|}{ Products } \\
\hline & (g) & $\begin{array}{c}\text { PMMA }^{a)} \\
\text { (Mol. Wt. }) \\
\left(\times 10^{-4}\right)\end{array}$ & $\begin{array}{l}\text { DMF } \\
(\mathrm{m} l)\end{array}$ & $\begin{array}{l}\text { TTA } \\
(\mathrm{m} l)\end{array}$ & $\begin{array}{l}\text { Temp. } \\
\left({ }^{\circ} \mathrm{C}\right)\end{array}$ & $\begin{array}{l}\text { Time } \\
(\mathrm{hr})\end{array}$ & & $\begin{array}{c}N \\
(\%)\end{array}$ & $\begin{array}{l}\text { Conver- } \\
\text { sion's) } \\
(\%)\end{array}$ & Symbol \\
\hline 1 & 1 & 204.3 & 80 & 10.5 & 175 & 7 & 1.01 & 13.9 & 34.6 & PMT 200 \\
\hline 2 & 1 & 76.8 & 80 & 10.5 & 175 & 7 & 0.97 & 13.9 & 34.6 & PMT 80 \\
\hline 3 & 1 & 28.9 & 40 & 10.5 & 175 & 7 & 1.18 & 15.1 & 39.0 & PMT 30 \\
\hline 4 & 1 & 5.6 & 40 & 10.5 & 175 & 7 & 1.41 & 14.8 & 37.8 & PMT 6 \\
\hline
\end{tabular}

a) PMMA were polymerized at $30^{\circ} \mathrm{C}, 40^{\circ} \mathrm{C}, 60^{\circ} \mathrm{C}$ and $100^{\circ} \mathrm{C}$ using $\mathrm{BPO}(0.5 \%)$ as initiator, respectively.

b), c) See Table 1 .

になるよらに DMF を加えて反応するとすべて水に可溶のるのが 得られた。結果を表1の No.9〜12 括よび図 2 に示す。

清澄效果は 3 倍モルのアミンを加えて反応させたるのは 3 倍以 上のアミンを加えて反応させた場合にくらべわずかに悪い。以上 の結果から反応液中のボリマー灌度とアミンの量が水溶性高分子 の生成に影響することが明らかになりアミンの量は 5〜7 倍モル 量が適当之考える。

\section{2 崩入アミノ基の程類と清澄効果}

PMMA と反応させるポリエチレンポリアミンを DTA，TTA， TPA と変えて，得られた凝集剤の性状と清澄効果を検討した。 結果を表 1 の No. 13〜15 と図3に示す。

DTA を反応させた場合，䂏秦の含有量が他のアミンを反心さ せた場合にくらべてやや小さい値を示したが，その清澄効果には とんど差は認められなかった。これは DTA を反応させた場合の 反応禹が 40\% と一番高いためと考兄られ, 清澄効果は窒素の含 有量と導入アミノ基量（反応率）との両者に影響されるすのと考 える。

\section{3 分子量上清澄効果}

同一種の高分子频集剤では分子量の大きいものはど㕠集効果が 増すことが報告されているが(2)，本研究では，重合度の異なる PMMA を作製しこれらをTTA と最適条件（表 2）で反応さ

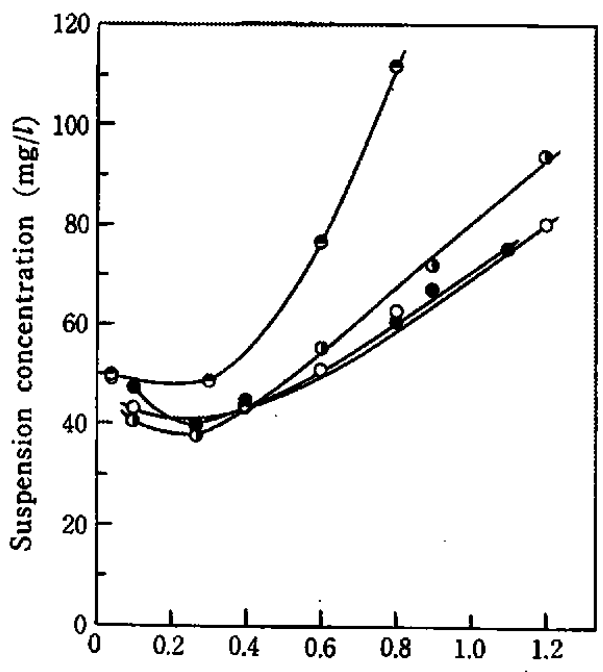

Amount of flocculants added (ppm)

Fig. 4 Effect of molecular weight of the flocculants.

: PMT 200, O : PMT 80, O : PMT 30,
: PMT 6 (See Table 2)

12）たとえ怗，費岛侑志，日化，82，1295(1961).
せて得られたすのの凝集効果をジャーテスターで検討した。重合 度の大きいPMMA の場合は溶媒を多量使用しないとポリマー溶 液の粘度が非常に高くなってアミンとの反度が起こりにくく，ま た反応中にゼりー状となり生成物の水に対する溶解珄が偠かっ た。結果を図 4 に示す。重合度の異なる PMMA は開始剂を一定 にして唒合温度を変えて封管中で塊状重合を行なって合成した。 得られた PMMA は精製しアセトン溶液の粘度を測定し，榀限粘 度式 $[\eta]=K M^{a}\left(K=0.75 \times 10^{-4}, a=0.70\right)^{13)}$ から 粘度 平均分子 量を求めた。

これらの結果から分子量が大きいPMMA から得られたるの㤝 ど清澄効果は大で豊島らの報告 ${ }^{12)}$ と一致するが，本凝集斉の陚合 分子量が 30 万以上のbのについてはほとんどその差が影められ なかった。

\section{4 浐用 $\mathrm{pH}$ 城}

合成した凝集凧 PMT-1C (表 1 参照) を使用し; 最道添加量 の $0.2 \mathrm{ppm}$ を加えて $\mathrm{pH}$ の異なるカオリン称濁液に対する清港 効果をジャーテスターで倹討した。結果を図 5 に示す。酸性側は 塩酸でアルカリ性側は水酸化ナトリウム溶液を加えて $\mathrm{pH}$ を調節 した。

この結果から合成した高分子凝集剤は $\mathrm{pH} 2.5$ 8.5 の䈟囲で

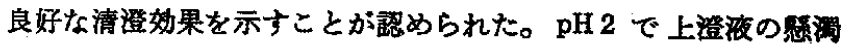
質瀑度が下がるのは㙁酸による凝結作用との相乘作用によるすの と考える。また pH 10 で急湤に上澄液の 蒸濁質濃度が上昇する がこれは導入されたアミノ基の解離がそれ以上の $\mathrm{pH} て ゙$ 㧕制され

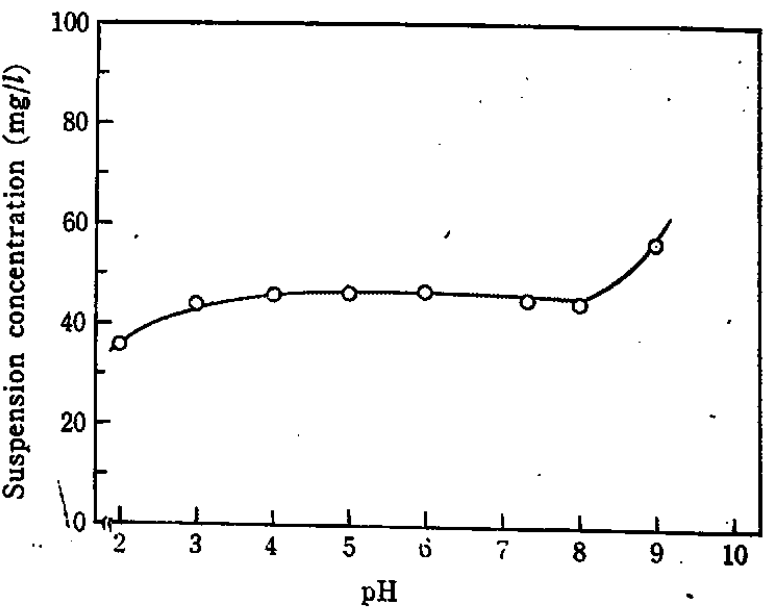

Fig. 5 Influence of $\mathrm{pH}$ on the clarification effect. sample: PMT 80, 0.2 ppm addition

13) J.Bishoff, V.Desreux, J. Polym. Sci., 10, 437 (1953). 


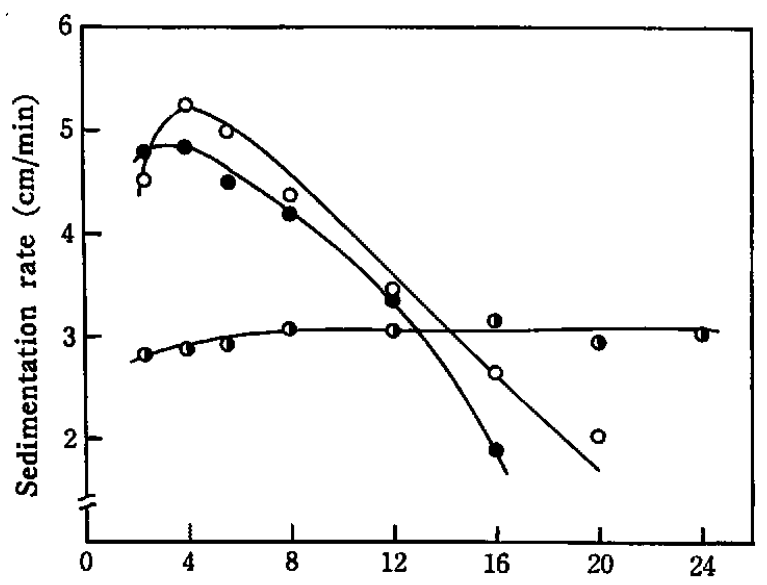

Amount of floculants added $\left(\% \times 10^{8}\right.$ to kaolin)

Fig. 6 Relation between the sedimentation rate and the amounts of flocculants added

O : PMT 200, : PMT 30, O : PMT 6

ることに基づくすのと耉える。

\section{6 沈降速度}

沈降速度の測定結果を図 6 に示す。試料は分子量の異なるPMT 200, PMT 30，PMT 6 (表 2 参照) を使用した。
この結果から最高の沈降速度は分子量の大きいすのは大なく PMT 200，PMT 30 の場合はカオリンに対する使用量が $0.004 \%$ でそれぞれ $5.2,4.8 \mathrm{~cm} / \mathrm{min}$ の值を示し，PMT 6 の場合蚛 $0.006 \%$ で $3 \mathrm{~cm} / \mathrm{min}$ の値を示した。なお PMT 80 は PMT 30 とほとんと同じ傾向を示したので図には省略した。PMT 6 の場 合は分子量む小さく生成するフロックむ小さく，カオリンに対す る使用墨が増加しても沈降速度はほぼ一定であったが分子量の大 きいPMT 200 と PMT 30 の場合，カオリンに対する使用量が 0.004\% 以上になると急激に沈降速度が低下した。また沈降容嫧 は本実験のカオリンに対する使用量の範囲では, 添加量の增大と ともに増大した。このようにある添加量以上に打いて沈降速度が 低下するが沈降容積は增大する点について坂ロら グリゲートが強い足場構造を形成して凝似分散現象を示すためと 考之ている。

以上の結果から PMMA とポりエチレンポリアミンとの反応に

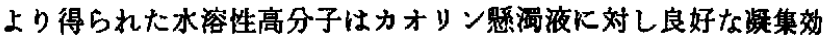
果を示すことが琶められた。

（1970 年 4 月，日本化学会第 23 年会 (一部) 発表)

14）坂口嘉平，長瀬邦彦，工化，69，1187(1966).

\title{
Synthesis of Cationic Polymers from Polymethyl Methacrylate and Their Flocculation Effect ${ }^{\dagger}$
}

\author{
Hiroaki Egawa, Takamasa Nonaka and Nobuyuki Ikeguchi \\ Faculty of Engineering, Kumamoto University ; \\ Kurokami-machi, Kumamoto-shi, Japan
}

Water-soluble cationic polymers were prepared by the aminolysis of polymethylmethacrylate (PMMA) with polyethylenepolyamine. The application of the polymer to cationic flocculation effect for kaolin suspensions was investigated. The flocculation effect was studied by observing the supernatant suspension concentration after 2 minutues in jar test and the sedimentation rate by the test tube.

The best flocculation effect was obtained when PMMA(M. W. $3 \sim 20 \times 10^{5}$ ) were treated with $5 \sim 10 \mathrm{~mol}$ polyethylenepolyamines (to ester groups) in dimethylformamide at $170 \sim 180^{\circ} \mathrm{C}$ for 5 7 hours. Diethylenetriamine, triethylenetetramine and tetraethylenepentamine gave similar efficiencies. The suitable concentration range to the $500 \mathrm{mg} / l$ kaolin suspensions was $0.1 \sim 1.0$ ppm and the supernatant concentration at the optimum dosage was below $40 \mathrm{mg} / \mathrm{l}$. The cationic polymers are most effective in the $\mathrm{pH}$ range of $2.5 \sim 8.5$. The maximum rate of sedimentation was $5.25 \mathrm{~cm} / \mathrm{min}$, when the amount of the polymers was $0.004 \%$ with respect to kaolin.

$\dagger$ Studies on Polymeric Flocculants. I. 